\title{
Florida Beekeeping Management Calendar ${ }^{1}$
}

\author{
James D. Ellis, Mary C. Bammer, and William H. Kern²
}

Climate, plant communities, and timing of floral resources differ significantly between the three main regions in Florida: north Florida, central Florida, and south Florida. North Florida encompasses the panhandle region, down through Alachua, Levy, Putnam, and Flagler counties. Central Florida includes Marion County down through Sarasota County. South Florida encompasses the remaining counties including the Keys (Figure 1). Because of this variability, managing European honey bee colonies in Florida differs across these regions throughout the year.

The following beekeeper management calendar was created for beekeepers in Florida. It is specific to region (north, central, south Florida) and month. The calendar includes recommendations for major management considerations like when to treat for parasites or pathogens and when to feed colonies or harvest honey. This management calendar is not exhaustive. It is meant merely as a reference or starting point for honey bee colony management in Florida. It is important that Florida beekeepers consult their local UF/ IFAS Extension office (http://solutionsforyourlife.ufl.edu/

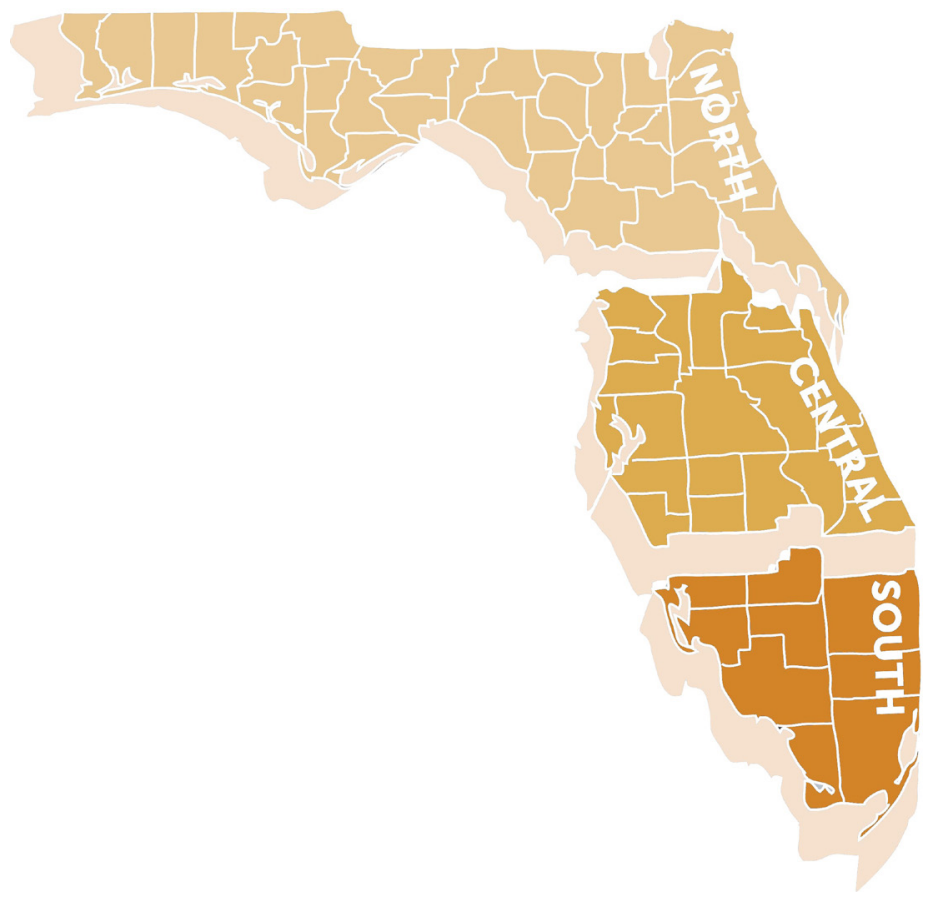

Figure 1. map/) or Apiary Inspector (http://www.freshfromflorida. com/Divisions-Offices/Plant-Industry/Bureaus-andServices/Office-Locations/Apiary-Inspector-Directory) should any specific management questions arise. When considering treating colonies with pesticides, always follow label instructions; the label is the law.

1. This document is ENY156, one of a series of the Department of Entomology and Nematology, UF/IFAS Extension. Original publication date May 2010. Revised November 2013 and July 2018. Visit the EDIS website at http://edis.ifas.ufl.edu.

2. James D. Ellis, associate professor; Mary C. Bammer, Extension coordinator, Entomology \& Nematology Department; and William H. Kern, Jr., associate professor; Entomology and Nematology Department, UF/IFAS Fort Lauderdale Research and Education Center; UF/IFAS Extension, Gainesville, FL 32611.

The Institute of Food and Agricultural Sciences (IFAS) is an Equal Opportunity Institution authorized to provide research, educational information and other services

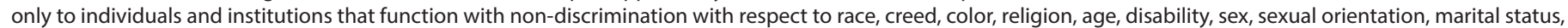

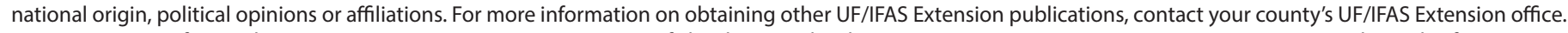
U.S. Department of Agriculture, UF/IFAS Extension Service, University of Florida, IFAS, Florida A \& M University Cooperative Extension Program, and Boards of County Commissioners Cooperating. Nick T. Place, dean for UF/IFAS Extension. 
Table 1. Beekeeping Management Calendar for North Florida

\begin{tabular}{|c|c|}
\hline Month & Management Recommendations \\
\hline \multirow[t]{3}{*}{ January } & 1) Feed colonies if light. (Colonies can starve!) \\
\hline & $\begin{array}{l}\text { 2) Nosema can be a significant colony problem this time of year. Making sure colonies are well fed will reduce Nosema } \\
\text { spore counts (one million spores per bee is considered a high spore count). For information on monitoring Nosema in } \\
\text { colonies, see How to Quantify Nosema Spores Infection Rate in a Honey Bee Colony (http://edis.ifas.ufl.edu/in1123). }\end{array}$ \\
\hline & $\begin{array}{l}\text { 3) Repair/paint old equipment. For more information, see Preserving Woodenware in Beekeeping Operations (http://edis.ifas. } \\
\text { ufl.edu/aa244). }\end{array}$ \\
\hline \multirow[t]{2}{*}{ February } & 1) Queen issues are especially problematic this time of year. Remedy failing queens as necessary. \\
\hline & $\begin{array}{l}\text { 2) Feed colonies if light. (Colonies can starve!) Also supply pollen supplements if necessary. For more information on } \\
\text { ensuring colony nutrition, see The Benefits of Pollen to Honey Bees (http://edis.ifas.ufl.edu/in868). }\end{array}$ \\
\hline \multirow[t]{4}{*}{ March } & $\begin{array}{l}\text { 1) Nosema can be a significant colony problem this time of year. Making sure colonies are well fed will reduce Nosema } \\
\text { spore counts (one million spores per bee is considered a high spore count). For information on monitoring Nosema in } \\
\text { colonies, see How to Quantify Nosema Spores Infection Rate in a Honey Bee Colony (http://edis.ifas.ufl.edu/in1123). }\end{array}$ \\
\hline & $\begin{array}{l}\text { 2) Colonies can be treated with Terramycin (oxytetracycline) or Tylan (tylsoin) for American foulbrood (AFB) prevention or } \\
\text { Lincomix (lincomycin) or Terramycin (oxytetracycline) for European foulbrood (EFB). These products require a prescription } \\
\text { or a veterinary feed directive from a veterinarian. For more information on rules surrounding prescription antibiotics for } \\
\text { honey bees, see "Using Medically Important Antimicrobials in Bees- Questions and Answers" (https://www.fda.gov/ } \\
\text { AnimalVeterinary/DevelopmentApprovalProcess/ucm589399.htm). }\end{array}$ \\
\hline & $\begin{array}{l}\text { 3) Colony populations begin to grow. Add supers and/or control swarming as necessary. For more information on } \\
\text { controlling swarms, see Swarm Control for Managed Beehives (http://edis.ifas.ufl.edu/in970). }\end{array}$ \\
\hline & 4) Make nucs/splits. \\
\hline \multirow[t]{4}{*}{ April } & 1) Queen issues are especially problematic this time of year. Remedy failing queens as necessary. \\
\hline & $\begin{array}{l}\text { 2) Continue to control swarming. For more information, see Swarm Control for Managed Beehives (http://edis.ifas.ufl.edu/ } \\
\text { in970). }\end{array}$ \\
\hline & 3) Make nucs/splits as new queens and packages become available. \\
\hline & 4) Add supers; the primary nectar flow begins this month. \\
\hline \multirow[t]{3}{*}{ May } & 1) Queen issues are especially problematic this time of year. Remedy failing queens as necessary. \\
\hline & $\begin{array}{l}\text { 2) Continue to control swarming. For more information, see Swarm Control for Managed Beehives (http://edis.ifas.ufl.edu/ } \\
\text { in970). }\end{array}$ \\
\hline & 3) Super as necessary. \\
\hline \multirow[t]{2}{*}{ June } & $\begin{array}{l}\text { 1) Varroa populations begin to grow, so monitor your colonies. Consider treating when Varroa levels reach } 3 \% \text { ( } 3 \text { mites } \\
\text { per } 100 \text { bees as determined by an alcohol wash or a sugar shake). Treatment options include: Apiguard, Apistan, Apivar, } \\
\text { Hopguard, and Mite Away (always follow label instructions). For information on how to monitor for varroa, read "Tools } \\
\text { for Varroa Management" (http://honeybeehealthcoalition.org/wp-content/uploads/2016/11/HBHC-Guide_Varroa_- } \\
\text { Interactive_v5_310ctober2016.pdf), and watch "Sampling Methods" (https://youtu.be/lgPfT9FQxLc). }\end{array}$ \\
\hline & $\begin{array}{l}\text { 2) Remove and process honey; main flow slows. For more information, see Bottling, Labeling, and Selling Honey in Florida } \\
\text { (http://edis.ifas.ufl.edu/in918). }\end{array}$ \\
\hline \multirow[t]{2}{*}{ July } & $\begin{array}{l}\text { 1) Monitor for Varroa. Consider treating when Varroa levels reach } 3 \% \text { ( } 3 \text { mites per } 100 \text { bees as determined by an alcohol } \\
\text { wash or a sugar shake). Treatment options include: Apiguard, Apistan, Apivar, Hopguard, and Mite Away (always } \\
\text { follow label instructions). For information on how to monitor for Varroa read "Tools for Varroa Management" (http:// } \\
\text { honeybeehealthcoalition.org/wp-content/uploads/2016/11/HBHC-Guide_Varroa_Interactive_v5_31October2016.pdf), } \\
\text { and watch "Sampling Methods" (https://youtu.be/IgPfT9FQxLc). }\end{array}$ \\
\hline & $\begin{array}{l}\text { 2) Remove and process honey; main flow stops. For more information, see Bottling, Labeling, and Selling Honey in Florida } \\
\text { (http://edis.ifas.ufl.edu/in918). }\end{array}$ \\
\hline
\end{tabular}




\begin{tabular}{|c|c|}
\hline \multirow[t]{5}{*}{ August } & 1) Feed colonies if light. (Colonies can starve!) \\
\hline & $\begin{array}{l}\text { 2) Monitor for Varroa. Consider treating when Varroa levels reach 3\% ( } 3 \text { mites per } 100 \text { bees as determined by an alcohol } \\
\text { wash or a sugar shake). Treatment options include: Apiguard, Apistan, Apivar, Hopguard, and Mite Away (always } \\
\text { follow label instructions). For information on how to monitor for Varroa read "Tools for Varroa Management" (http:// } \\
\text { honeybeehealthcoalition.org/wp-content/uploads/2016/11/HBHC-Guide_Varroa_Interactive_v5_31October2016.pdf), } \\
\text { and watch "Sampling Methods" (https://youtu.be/IgPfT9FQxLc). }\end{array}$ \\
\hline & $\begin{array}{l}\text { 3) Colonies can be treated with Terramycin (oxytetracycline) or Tylan (tylsoin) for American foulbrood (AFB) prevention or } \\
\text { Lincomix (lincomycin) or Terramycin (oxytetracycline) for European foulbrood (EFB). These products require a prescription } \\
\text { or a veterinary feed directive from a veterinarian. For more information on rules surrounding prescription antibiotics } \\
\text { for honey bees, see "Using Medically Important Antimicrobials in Bees-Questions and Answers" (https://www.fda.gov/ } \\
\text { AnimalVeterinary/DevelopmentApprovalProcess/ucm589399.htm). }\end{array}$ \\
\hline & $\begin{array}{l}\text { 4) Monitor and control for small hive beetles. Control options include GardStar and in-hive beetle traps (Hood trap, West } \\
\text { beetle trap, Beetle Blaster, etc.). Always follow pesticide label instructions. For more information, see Small Hive Beetle, } \\
\text { Aethina tumida Murray (http://edis.ifas.ufl.edu/in854). }\end{array}$ \\
\hline & 5) It's hot! Ensure adequate colony ventilation. \\
\hline \multirow[t]{3}{*}{ September } & 1) Feed colonies if light. (Colonies can starve!) \\
\hline & $\begin{array}{l}\text { 2) Monitor for Varroa. Consider treating when Varroa levels reach } 3 \% \text { ( } 3 \text { mites per } 100 \text { bees as determined by an alcohol } \\
\text { wash or a sugar shake). Treatment options include: Apiguard, Apistan, Apivar, Hopguard, and Mite Away (always } \\
\text { follow label instructions). For information on how to monitor for Varroa read "Tools for Varroa Management" (http:// } \\
\text { honeybeehealthcoalition.org/wp-content/uploads/2016/11/HBHC-Guide_Varroa_Interactive_v5_31October2016.pdf), } \\
\text { and watch "Sampling Methods" (https://youtu.be/IgPfT9FQxLc). }\end{array}$ \\
\hline & $\begin{array}{l}\text { 3) Nosema can be a significant colony problem this time of year. Making sure colonies are well fed will reduce Nosema } \\
\text { spore counts (one million spores per bee is considered a high spore count). For information on monitoring Nosema in } \\
\text { colonies, see How to Quantify Nosema Spores Infection Rate in a Honey Bee Colony (http://edis.ifas.ufl.edu/in1123). }\end{array}$ \\
\hline \multirow{4}{*}{$\begin{array}{l}\text { October - } \\
\text { December }\end{array}$} & 1) Feed colonies if light. (Colonies can starve!) \\
\hline & $\begin{array}{l}\text { 2) Monitor for Varroa. Consider treating when Varroa levels reach } 3 \% \text { ( } 3 \text { mites per } 100 \text { bees as determined by an alcohol } \\
\text { wash or a sugar shake). Treatment options include: Apiguard, Apistan, Apivar, Hopguard, and Mite Away (always } \\
\text { follow label instructions). For information on how to monitor for Varroa read "Tools for Varroa Management" (http:// } \\
\text { honeybeehealthcoalition.org/wp-content/uploads/2016/11/HBHC-Guide_Varroa_Interactive_v5_31October2016.pdf), } \\
\text { and watch "Sampling Methods" (https://youtu.be/lgPfT9FQxLc). }\end{array}$ \\
\hline & $\begin{array}{l}\text { 3) You can treat colonies for Nosema disease this time of year. Making sure colonies are well fed will reduce Nosema spore } \\
\text { counts (one million spores per bee is considered a high spore count). Some beekeepers also treat colonies with fumagilin } \\
\text { with varied effectiveness (always follow label instructions). Recheck spore counts in colonies } 2-3 \text { weeks after treatment. } \\
\text { For information on monitoring Nosema in colonies, see "How to Quantify Nosema Spores Infection Rate in a Honey Bee } \\
\text { Colony" (http://edis.ifas.ufl.edu/in1123). }\end{array}$ \\
\hline & $\begin{array}{l}\text { 4) Monitor and control for small hive beetles. Control options include GardStar and in-hive beetle traps (Hood trap, West } \\
\text { beetle trap, Beetle Blaster, etc.). Always follow pesticide label instructions. For more information, see Small Hive Beetle, } \\
\text { Aethina tumida Murray (http://edis.ifas.ufl.edu/in854). }\end{array}$ \\
\hline
\end{tabular}


Table 2. Beekeeping Management Calendar for Central Florida

\begin{tabular}{|c|c|}
\hline Month & Management Recommendations \\
\hline \multirow[t]{3}{*}{ January } & $\begin{array}{l}\text { 1) Feed colonies if light. (Colonies can starve!) Also supply pollen supplements if necessary. For more information on } \\
\text { ensuring colony nutrition, see The Benefits of Pollen to Honey Bees (http://edis.ifas.ufl.edu/in868). }\end{array}$ \\
\hline & $\begin{array}{l}\text { 2) Nosema can be a significant colony problem this time of year. Making sure colonies are well fed will reduce Nosema } \\
\text { spore counts (one million spores per bee is considered a high spore count). For information on monitoring Nosema in } \\
\text { colonies, see How to Quantify Nosema Spores Infection Rate in a Honey Bee Colony (http://edis.ifas.ufl.edu/in1123). }\end{array}$ \\
\hline & $\begin{array}{l}\text { 3) Repair/paint old equipment. For more information, see Preserving Woodenware in Beekeeping Operations (http://edis. } \\
\text { ifas.ufl.edu/aa244). }\end{array}$ \\
\hline \multirow[t]{3}{*}{ February } & 1) Feed colonies if light. (Colonies can starve!) \\
\hline & $\begin{array}{l}\text { 2) Nosema can be a significant colony problem this time of year. Making sure colonies are well fed will reduce Nosema } \\
\text { spore counts (one million spores per bee is considered a high spore count). For information on monitoring Nosema in } \\
\text { colonies, see How to Quantify Nosema Spores Infection Rate in a Honey Bee Colony (http://edis.ifas.ufl.edu/in1123). }\end{array}$ \\
\hline & $\begin{array}{l}\text { 3) Colonies can be treated with Terramycin (oxytetracycline) or Tylan (tylsoin) for American foulbrood (AFB) prevention } \\
\text { or Lincomix (lincomycin) or Terramycin (oxytetracycline) for European foulbrood (EFB). These products require a } \\
\text { prescription or a veterinary feed directive from a veterinarian. For more information on rules surrounding prescription } \\
\text { antibiotics for honey bees, "Using Medically Important Antimicrobials in Bees - Questions and Answers” (https://www. } \\
\text { fda.gov/AnimalVeterinary/DevelopmentApprovalProcess/ucm589399.htm). }\end{array}$ \\
\hline \multirow[t]{5}{*}{ March } & 1) Queen issues are especially problematic this time of year. Remedy failing queens as necessary. \\
\hline & $\begin{array}{l}\text { 2) Begin to monitor for Varroa. Consider treating when Varroa levels reach } 3 \% \text { ( } 3 \text { mites per } 100 \text { bees as determined by an } \\
\text { alcohol wash or a sugar shake). Treatment options include: Apiguard, Apistan, Apivar, Hopguard, and Mite Away (always } \\
\text { follow label instructions). For information on how to monitor for Varroa read "Tools for Varroa Management" (http:// } \\
\text { honeybeehealthcoalition.org/wp-content/uploads/2016/11/HBHC-Guide_Varroa_Interactive_v5_31October2016.pdf), } \\
\text { and watch "Sampling Methods" (https://youtu.be/lgPfT9FQxLc). }\end{array}$ \\
\hline & $\begin{array}{l}\text { 3) Colonies can be treated with Terramycin (oxytetracycline) or Tylan (tylsoin) for American foulbrood (AFB) prevention } \\
\text { or Lincomix (lincomycin) or Terramycin (oxytetracycline) for European foulbrood (EFB). These products require a } \\
\text { prescription or a veterinary feed directive from a veterinarian. For more information on rules surrounding prescription } \\
\text { antibiotics for honey bees, "Using Medically Important Antimicrobials in Bees - Questions and Answers” (https://www. } \\
\text { fda.gov/AnimalVeterinary/DevelopmentApprovalProcess/ucm589399.htm). }\end{array}$ \\
\hline & $\begin{array}{l}\text { 4) Colony populations begin to grow. Add supers and/or control swarming as necessary. For more information on } \\
\text { controlling swarms, see Swarm Control for Managed Beehives (http://edis.ifas.ufl.edu/in970). }\end{array}$ \\
\hline & 5) Make nucs/splits. \\
\hline \multirow[t]{4}{*}{ April } & 1) Queen issues are especially problematic this time of year. Remedy failing queens as necessary. \\
\hline & $\begin{array}{l}\text { 2) Continue to control swarming. For more information, see "Swarm Control for Managed Beehives" (http://edis.ifas.ufl. } \\
\text { edu/in970). }\end{array}$ \\
\hline & 3) Make nucs/splits as new queens and packages become available. \\
\hline & 4) Super as necessary. \\
\hline \multirow[t]{3}{*}{ May } & 1) Queen issues are especially problematic this time of year. Remedy failing queens as necessary. \\
\hline & $\begin{array}{l}\text { 2) Continue to control swarming. For more information, see "Swarm Control for Managed Beehives" (http://edis.ifas.ufl. } \\
\text { edu/in970). }\end{array}$ \\
\hline & 3) Super as necessary. \\
\hline \multirow[t]{2}{*}{ June } & $\begin{array}{l}\text { 1) Varroa populations begin to grow, so monitor your colonies. Consider treating when Varroa levels reach } 3 \% \text { (3 mites } \\
\text { per } 100 \text { bees as determined by an alcohol wash or a sugar shake). Treatment options include: Apiguard, Apistan, Apivar, } \\
\text { Hopguard, and Mite Away (always follow label instructions). For information on how to monitor for Varroa read "Tools } \\
\text { for Varroa Management" (http://honeybeehealthcoalition.org/wp-content/uploads/2016/11/HBHC-Guide_Varroa_ } \\
\text { Interactive_v5_310ctober2016.pdf), and watch "Sampling Methods" (https://youtu.be/lgPfT9FQxLc). }\end{array}$ \\
\hline & $\begin{array}{l}\text { 2) Remove and process honey; main flow slows. For more information, see Bottling, Labeling, and Selling Honey in Florida } \\
\text { (http://edis.ifas.ufl.edu/in918). }\end{array}$ \\
\hline \multirow[t]{2}{*}{ July } & $\begin{array}{l}\text { 1) Monitor for Varroa. Consider treating when Varroa levels reach } 3 \% \text { ( } 3 \text { mites per } 100 \text { bees as determined by an alcohol } \\
\text { wash or a sugar shake). Treatment options include: Apiguard, Apistan, Apivar, Hopguard, and Mite Away (always } \\
\text { follow label instructions). For information on how to monitor for Varroa read "Tools for Varroa Management" (http:// } \\
\text { honeybeehealthcoalition.org/wp-content/uploads/2016/11/HBHC-Guide_Varroa_Interactive_v5_31October2016.pdf), } \\
\text { and watch "Sampling Methods" (https://youtu.be/IgPfT9FQxLc). }\end{array}$ \\
\hline & $\begin{array}{l}\text { 2) Remove and process honey; main flow stops. For more information, see Bottling, Labeling, and Selling Honey in Florida } \\
\text { (http://edis.ifas.ufl.edu/in918). }\end{array}$ \\
\hline
\end{tabular}




\begin{tabular}{|c|c|}
\hline \multirow[t]{5}{*}{ August } & 1) Feed colonies if light. (Colonies can starve!) \\
\hline & $\begin{array}{l}\text { 2) Monitor for Varroa. Consider treating when Varroa levels reach } 3 \% \text { ( } 3 \text { mites per } 100 \text { bees as determined by an alcohol } \\
\text { wash or a sugar shake). Treatment options include: Apiguard, Apistan, Apivar, Hopguard, and Mite Away (always } \\
\text { follow label instructions). For information on how to monitor for Varroa, read "Tools for Varroa Management" (http:// } \\
\text { honeybeehealthcoalition.org/wp-content/uploads/2016/11/HBHC-Guide_Varroa_Interactive_v5_31October2016.pdf), } \\
\text { and watch "Sampling Methods" (https://youtu.be/lgPfT9FQxLc). }\end{array}$ \\
\hline & $\begin{array}{l}\text { 3) Colonies can be treated with Terramycin (oxytetracycline) or Tylan (tylsoin) for American foulbrood (AFB) prevention } \\
\text { or Lincomix (lincomycin) or Terramycin (oxytetracycline) for European foulbrood (EFB). These products require a } \\
\text { prescription or a veterinary feed directive from a veterinarian. For more information on rules surrounding prescription } \\
\text { antibiotics for honey bees, see "Using Medically Important Antimicrobials in Bees-Questions and Answers" (https:// } \\
\text { www.fda.gov/AnimalVeterinary/DevelopmentApprovalProcess/ucm589399.htm). }\end{array}$ \\
\hline & $\begin{array}{l}\text { 4) Monitor and control for small hive beetles. Control options include GardStar and in-hive beetle traps (Hood trap, West } \\
\text { beetle trap, Beetle Blaster, etc.). Always follow pesticide label instructions. For more information, see Small Hive Beetle, } \\
\text { Aethina tumida Murray (http://edis.ifas.ufl.edu/in854). }\end{array}$ \\
\hline & 5) It's hot! Ensure adequate colony ventilation. \\
\hline \multirow[t]{4}{*}{ September } & 1) If no nectar flow, feed colonies if light. \\
\hline & $\begin{array}{l}\text { 2) Monitor for Varroa. Consider treating when Varroa levels reach 3\% (3 mites per } 100 \text { bees as determined by an alcohol } \\
\text { wash or a sugar shake). Treatment options include: Apiguard, Apistan, Apivar, Hopguard, and Mite Away (always } \\
\text { follow label instructions). For information on how to monitor for Varroa read "Tools for Varroa Management" (http:// } \\
\text { honeybeehealthcoalition.org/wp-content/uploads/2016/11/HBHC-Guide_Varroa_Interactive_v5_31October2016.pdf), } \\
\text { and watch "Sampling Methods" (https://youtu.be/lgPfT9FQxLc). }\end{array}$ \\
\hline & $\begin{array}{l}\text { 3) Nosema can be a significant colony problem this time of year. Making sure colonies are well fed will reduce Nosema } \\
\text { spore counts (one million spores per bee is considered a high spore count). For information on monitoring Nosema in } \\
\text { colonies, see How to Quantify Nosema Spores Infection Rate in a Honey Bee Colony (http://edis.ifas.ufl.edu/in1123). }\end{array}$ \\
\hline & 4) Super colonies if there is a strong Brazilian pepper flow. \\
\hline \multirow[t]{4}{*}{ October-December } & 1) Feed colonies if light. (Colonies can starve!) \\
\hline & $\begin{array}{l}\text { 2) Varroa populations peaked in Aug/Sept, but continue to monitor colonies. Consider treating when Varroa levels reach } \\
3 \% \text { ( } 3 \text { mites per } 100 \text { bees as determined by an alcohol wash or a sugar shake). Treatment options include: Apiguard, } \\
\text { Apistan, Apivar, Hopguard, and Mite Away (always follow label instructions). For information on how to monitor for } \\
\text { Varroa read “Tools for Varroa Management" (http://honeybeehealthcoalition.org/wp-content/uploads/2016/11/HBHC- } \\
\text { Guide_Varroa_Interactive_v5_31October2016.pdf), and watch "Sampling Methods" (https://youtu.be/lgPfT9FQxLc). }\end{array}$ \\
\hline & $\begin{array}{l}\text { 3) Nosema can be a significant colony problem this time of year. Making sure colonies are well fed will reduce Nosema } \\
\text { spore counts (one million spores per bee is considered a high spore count). For information on monitoring Nosema in } \\
\text { colonies, see How to Quantify Nosema Spores Infection Rate in a Honey Bee Colony (http://edis.ifas.ufl.edu/in1123). }\end{array}$ \\
\hline & $\begin{array}{l}\text { 4) Monitor and control for small hive beetles. Control options include GardStar and in-hive beetle traps (Hood trap, West } \\
\text { beetle trap, Beetle Blaster, etc.). Always follow pesticide label instructions. For more information, see Small Hive Beetle, } \\
\text { Aethina tumida Murray (http://edis.ifas.ufl.edu/in854). }\end{array}$ \\
\hline
\end{tabular}


Table 3. Beekeeping Management Calendar for South Florida

\begin{tabular}{|c|c|}
\hline Month & Management Recommendations \\
\hline \multirow[t]{3}{*}{ January } & $\begin{array}{l}\text { 1) Feed colonies if light. (Colonies can starve!) Also supply pollen supplements if necessary. For more information } \\
\text { on ensuring colony nutrition, see The Benefits of Pollen to Honey Bees (http://edis.ifas.ufl.edu/in868). }\end{array}$ \\
\hline & $\begin{array}{l}\text { 2) Nosema can be a significant colony problem this time of year. Making sure colonies are well fed will reduce } \\
\text { Nosema spore counts (one million spores per bee is considered a high spore count). For information on monitoring } \\
\text { Nosema in colonies, see How to Quantify Nosema Spores Infection Rate in a Honey Bee Colony (http://edis.ifas.ufl.edu/ } \\
\text { in1123). }\end{array}$ \\
\hline & $\begin{array}{l}\text { 3) Repair/paint old equipment. For more information, see Preserving Woodenware in Beekeeping Operations (http:// } \\
\text { edis.ifas.ufl.edu/aa244). }\end{array}$ \\
\hline \multirow[t]{4}{*}{ February } & 1) Feed colonies if light. (Colonies can starve!) \\
\hline & $\begin{array}{l}\text { 2) Nosema can be a significant colony problem this time of year. Making sure colonies are well fed will reduce } \\
\text { Nosema spore counts (one million spores per bee is considered a high spore count). For information on monitoring } \\
\text { Nosema in colonies, see How to Quantify Nosema Spores Infection Rate in a Honey Bee Colony (http://edis.ifas.ufl.edu/ } \\
\text { in1123). }\end{array}$ \\
\hline & $\begin{array}{l}\text { 3) Colonies can be treated with Terramycin (oxytetracycline) or Tylan (tylsoin) for American foulbrood (AFB) } \\
\text { prevention or Lincomix (lincomycin) or Terramycin (oxytetracycline) for European foulbrood (EFB). These products } \\
\text { require a prescription or a veterinary feed directive from a veterinarian. For more information on rules surrounding } \\
\text { prescription antibiotics for honey bees, see "Using Medically Important Antimicrobials in Bees—Questions and } \\
\text { Answers" (https://www.fda.gov/AnimalVeterinary/DevelopmentApprovalProcess/ucm589399.htm). }\end{array}$ \\
\hline & 4) Make nucs/splits. \\
\hline \multirow[t]{3}{*}{ March } & 1) Queen issues are especially problematic this time of year. Remedy failing queens as necessary. \\
\hline & $\begin{array}{l}\text { 2) Colonies can be treated with Terramycin (oxytetracycline) or Tylan (tylsoin) for American foulbrood (AFB) } \\
\text { prevention or Lincomix (lincomycin) or Terramycin (oxytetracycline) for European foulbrood (EFB). These products } \\
\text { require a prescription or a veterinary feed directive from a veterinarian. For more information on rules surrounding } \\
\text { prescription antibiotics for honey bees, see "Using Medically Important Antimicrobials in Bees-Questions and } \\
\text { Answers" (https://www.fda.gov/AnimalVeterinary/DevelopmentApprovalProcess/ucm589399.htm). }\end{array}$ \\
\hline & $\begin{array}{l}\text { 3) Colony populations begin to grow. Add supers and/or control swarming as necessary. For more information on } \\
\text { controlling swarms, see Swarm Control for Managed Beehives (http://edis.ifas.ufl.edu/in970). }\end{array}$ \\
\hline \multirow[t]{5}{*}{ April } & 1) Queen issues are especially problematic this time of year. Remedy failing queens as necessary. \\
\hline & $\begin{array}{l}\text { 2) Continue to control swarming. For more information, see Swarm Control for Managed Beehives (http://edis.ifas.ufl. } \\
\text { edu/in970). }\end{array}$ \\
\hline & 3) Make nucs/splits as new queens and packages become available. \\
\hline & 4) Super as necessary. \\
\hline & 5) Orange blossom honey can be extracted in late April. \\
\hline \multirow[t]{3}{*}{ May } & 1) Queen issues are especially problematic this time of year. Remedy failing queens as necessary. \\
\hline & $\begin{array}{l}\text { 2) Continue to control swarming. For more information, see Swarm Control for Managed Beehives (http://edis.ifas.ufl. } \\
\text { edu/in970). }\end{array}$ \\
\hline & 3) Super as necessary. \\
\hline \multirow[t]{3}{*}{ June } & $\begin{array}{l}\text { 1) Varroa populations begin to grow, so monitor your colonies. Consider treating when Varroa levels reach } 3 \% \\
\text { ( } 3 \text { mites per } 100 \text { bees as determined by an alcohol wash or a sugar shake). Treatment options include: Apiguard, } \\
\text { Apistan, Apivar, Hopguard, and Mite Away (always follow label instructions). For information on how to monitor } \\
\text { for Varroa read "Tools for Varroa Management" (http://honeybeehealthcoalition.org/wp-content/uploads/2016/11/ } \\
\text { HBHC-Guide_Varroa_Interactive_v5_31October2016.pdf), and watch "Sampling Methods" (https://youtu.be/ } \\
\text { IgPfT9FQxLc). }\end{array}$ \\
\hline & 2) Super as necessary for late flows. \\
\hline & $\begin{array}{l}\text { 3) If flow is over, remove and process honey. For more information on honey processing, see Bottling, Labeling, and } \\
\text { Selling Honey in Florida (http://edis.ifas.ufl.edu/in918). }\end{array}$ \\
\hline \multirow[t]{2}{*}{ July } & $\begin{array}{l}\text { 1) Monitor for Varroa. Consider treating when Varroa levels reach } 3 \% \text { ( } 3 \text { mites per } 100 \text { bees as determined by an } \\
\text { alcohol wash or a sugar shake). Treatment options include: Apiguard, Apistan, Apivar, Hopguard, and Mite Away } \\
\text { (always follow label instructions). For information on how to monitor for Varroa read "Tools for Varroa Management" } \\
\text { (http://honeybeehealthcoalition.org/wp-content/uploads/2016/11/HBHC-Guide_Varroa_Interactive_ } \\
\text { v5_310ctober2016.pdf), and watch"Sampling Methods" (https://youtu.be/lgPfT9FQxLc). }\end{array}$ \\
\hline & $\begin{array}{l}\text { 2) Remove and process honey; main flow stops. For more information on honey processing, see Bottling, Labeling, } \\
\text { and Selling Honey in Florida (http://edis.ifas.ufl.edu/in918). }\end{array}$ \\
\hline
\end{tabular}




\begin{tabular}{|c|c|}
\hline \multirow[t]{5}{*}{ August } & 1) Feed colonies if light. (Colonies can starve!) \\
\hline & $\begin{array}{l}\text { 2) Monitor for Varroa. Consider treating when Varroa levels reach } 3 \% \text { ( } 3 \text { mites per } 100 \text { bees as determined by an } \\
\text { alcohol wash or a sugar shake). Treatment options include: Apiguard, Apistan, Apivar, Hopguard, and Mite Away } \\
\text { (always follow label instructions). For information on how to monitor for Varroa read "Tools for Varroa Management" } \\
\text { (http://honeybeehealthcoalition.org/wp-content/uploads/2016/11/HBHC-Guide_Varroa_Interactive_ } \\
\text { v5_31October2016.pdf), and watch "Sampling Methods" (https://youtu.be/lgPfT9FQxLc). }\end{array}$ \\
\hline & $\begin{array}{l}\text { 3) Colonies can be treated with Terramycin (oxytetracycline) or Tylan (tylsoin) for American foulbrood (AFB) } \\
\text { prevention or Lincomix (lincomycin) or Terramycin (oxytetracycline) for European foulbrood (EFB). These products } \\
\text { require a prescription or a veterinary feed directive from a veterinarian. For more information on rules surrounding } \\
\text { prescription antibiotics for honey bees, see "Using Medically Important Antimicrobials in Bees—Questions and } \\
\text { Answers" (https://www.fda.gov/AnimalVeterinary/DevelopmentApprovalProcess/ucm589399.htm). }\end{array}$ \\
\hline & $\begin{array}{l}\text { 4) Monitor and control for small hive beetles. Control options include GardStar and in-hive beetle traps (Hood trap, } \\
\text { West beetle trap, Beetle Blaster, etc.). Always follow pesticide label instructions. For more information, see Small } \\
\text { Hive Beetle, Aethina tumida Murray (http://edis.ifas.ufl.edu/in854). }\end{array}$ \\
\hline & 5) It's hot! Ensure adequate colony ventilation. \\
\hline \multirow[t]{4}{*}{ September } & 1) If no nectar flow, feed colonies if light. \\
\hline & $\begin{array}{l}\text { 2) Monitor for Varroa. Consider treating when Varroa levels reach } 3 \% \text { ( } 3 \text { mites per } 100 \text { bees as determined by an } \\
\text { alcohol wash or a sugar shake). Treatment options include: Apiguard, Apistan, Apivar, Hopguard, and Mite Away } \\
\text { (always follow label instructions). For information on how to monitor for Varroa read "Tools for Varroa Management" } \\
\text { (http://honeybeehealthcoalition.org/wp-content/uploads/2016/11/HBHC-Guide_Varroa_Interactive_- } \\
\text { v5_31October2016.pdf), and watch "Sampling Methods" (https://youtu.be/IgPfT9FQxLc). }\end{array}$ \\
\hline & $\begin{array}{l}\text { 3) Nosema can be a significant colony problem this time of year. Making sure colonies are well fed will reduce } \\
\text { Nosema spore counts (one million spores per bee is considered a high spore count). For information on monitoring } \\
\text { Nosema in colonies, see How to Quantify Nosema Spores Infection Rate in a Honey Bee Colony (http://edis.ifas.ufl.edu/ } \\
\text { in 1123). }\end{array}$ \\
\hline & 4) Super colonies if there is a strong Brazilian pepper flow. \\
\hline \multirow[t]{4}{*}{ October-December } & 1) Feed colonies if light. (Colonies can starve!) \\
\hline & $\begin{array}{l}\text { 2) Monitor for Varroa. Consider treating when Varroa levels reach } 3 \% \text { ( } 3 \text { mites per } 100 \text { bees as determined by an } \\
\text { alcohol wash or a sugar shake). Treatment options include: Apiguard, Apistan, Apivar, Hopguard, and Mite Away } \\
\text { (always follow label instructions). For information on how to monitor for Varroa read "Tools for Varroa Management" } \\
\text { (http://honeybeehealthcoalition.org/wp-content/uploads/2016/11/HBHC-Guide_Varroa_Interactive_- } \\
\text { v5_31October2016.pdf), and watch "Sampling Methods" (https://youtu.be/lgPfT9FQxLc). }\end{array}$ \\
\hline & $\begin{array}{l}\text { 3) Nosema can be a significant colony problem this time of year. Making sure colonies are well fed will reduce } \\
\text { Nosema spore counts (one million spores per bee is considered a high spore count). For information on monitoring } \\
\text { Nosema in colonies, see How to Quantify Nosema Spores Infection Rate in a Honey Bee Colony (http://edis.ifas.ufl.edu/ } \\
\text { in1123). }\end{array}$ \\
\hline & $\begin{array}{l}\text { 4) Monitor and control for small hive beetles. Control options include GardStar and in-hive beetle traps (Hood trap, } \\
\text { West beetle trap, Beetle Blaster, etc.). Always follow pesticide label instructions. For more information, see Small } \\
\text { Hive Beetle, Aethina tumida Murray (http://edis.ifas.ufl.edu/in854). }\end{array}$ \\
\hline
\end{tabular}




\section{Selected References}

DeBerry, S., J. Crowley, and J. D. Ellis. 2012. Swarm Control for Managed Beehives. ENY-160. Gainesville: University of Florida Institute of Food and Agricultural Sciences. http:// edis.ifas.ufl.edu/in970

Ellis, J. D., W. H. Kern, and C. M. Zattel Nalen, 1992.

Preserving Woodenware in Beekeeping Operations. ENY-125. Gainesville: University of Florida Institute of Food and Agricultural Sciences. http://edis.ifas.ufl.edu/aa244

Ellis, J. D. and A. Ellis. 2010. Small Hive Beetle, Aethina tumida Murray (Insecta: Coleoptera: Nitidulidae). EENY474. Gainesville: University of Florida Institute of Food and Agricultural Sciences. http://edis.ifas.ufl.edu/in854

Ellis, A., J.D. Ellis, M. K. O’Malley, and C. M. Zettel Nalen. 2010. The Benefits of Pollen to Honey Bees. ENY-152. Gainesville: University of Florida Institute of Food and Agricultural Sciences. http://edis.ifas.ufl.edu/in868

Florida Department of Agriculture and Consumer Services. 2018. Apiary Inspector Directory. Retrieved from https://www.freshfromflorida.com/Divisions-Offices/ Plant-Industry/Bureaus-and-Services/Office-Locations/ Apiary-Inspector-Directory

Gentry, N. and J. D. Ellis. 2012. Bottling, Labeling, and Selling Honey in Florida. ENY-159. Gainesville: University of Florida Institute of Food and Agricultural Sciences. http:// edis.ifas.ufl.edu/in918

Honey Bee Health Coalition. (2016, November 4). 23 Sampling Methods 111116. Retrieved from https://www. youtube.com/watch?v=IgPfT9FQxLc\&feature=youtu.be

Honey Bee Health Coalition. 2016. Tools for Varroa Management: A Guide to Effective Varroa Sampling and Control. The Keystone Policy Center. Retrieved from https:// honeybeehealthcoalition.org/wp-content/uploads/2016/11/ HBHC-Guide_Varroa_Interactive_v5_31October2016.pdf

Mortensen, A. N, C, J, Jack, M. McConnell, L. Teigen, and J. D. Ellis. 2016. How to Quantify Nosema Spores Infection Rate in a Honey Bee Colony. ENY-167. Gainesville: University of Florida Institute of Food and Agricultural Sciences. http://edis.ifas.ufl.edu/in1123

United States Food and Drug Administration. 2017. Using Medically Important Antimicrobials in Bees - Questions and Answers. Retrieved from https://www.fda.gov/AnimalVeterinary/DevelopmentApprovalProcess/ucm589399.htm
University of Florida, Institute of Food and Agricultural Sciences, Extension. 2018. Districts, Directors and County Offices. Retrieved from http://sfyl.ifas.ufl.edu/ find-your-local-office/ 